\title{
Glutamine Amido Transferase in Yeast: Changes in Activity during the Cell Cycle
}

\author{
By J. H. DUFFUS, M. E. FINBOW, LINDA J. PATERSON \\ AND J. C. SLAUGHTER \\ Department of Brewing and Biological Sciences, Heriot-Watt University, \\ Edinburgh EHI I $H X$
}

(Received 4 February 1974; revised 4 March 1974)

\section{INTRODUCTION}

Glutamine amido transferase activity is of considerable interest in that it represents the simplest method of assaying glutamine synthetase (Shapiro \& Stadtman, 1970). This is a key enzyme in the metabolic processes leading to the incorporation of nitrogen into amino acids and nucleotides in both prokaryotic and eukaryotic cells (Prusiner \& Stadtman, 1973; Ferguson \& Sims, 197I, I 974 $a, b$; Sims \& Ferguson, 1974). The present paper reports a study of changes in glutamine amido transferase activity during the cell cycle in the budding yeast Kluyeromyces fragilis, formerly Saccharomyces fragilis (van der Walt, 1970).

\section{METHODS}

Kluyveromyces fragilis $\mathrm{NCYCIOO}$ was grown in Oxoid malt extract broth at $30^{\circ} \mathrm{C}$ in a Gallenkamp orbital incubator set at $160 \mathrm{rev} . \mathrm{min}$. Synchronous cultures were established by selection using the sucrose gradient technique of Mitchison \& Vincent (1965). Samples ( $10 \mathrm{ml}$ ) were taken at 10 min intervals and immediately frozen in a dry ice/ethanol bath. For analysis, the samples were thawed out and the cells sedimented by centrifuging at $850 \mathrm{~g}$ for Io min. The sedimented cells were washed twice by resuspension in cold ( $4 \mathrm{C}$ ) imidazole $-\mathrm{HCl}$ buffer $\left(\mathrm{O}^{\circ} \mathrm{I} \mathrm{M}, \mathrm{pH} 7 \cdot 0\right)$ followed by centrifuging. The final washed organisms were suspended in $2 \mathrm{ml}$ cold buffer and homogenized by a single passage through an Eaton press (Eaton, 1962). The homogenate was centrifuged as before to remove debris and the resultant supernatant liquid kept in ice. The glutamine amido transferase activity was assayed by the method of Shapiro \& Stadtman (1970). Cell numbers were measured in the original samples with a Thoma haemocytometer. Cytoplasmic division was taken to have occurred when the bud was two-thirds the size of the mother cell.

A study was made of the effects of selected metal ions, amino acids and nucleotides on the enzyme in homogenates prepared as above but with the addition of metal ions to the homogenizing medium and assay mixture where appropriate. Fresh solutions were always used in these assays as precipitation of imidazole-metal ion complexes occurred as solutions aged. The metal salts used were always chlorides. The concentrations quoted are those in the assay mixture.

\section{RESULTS}

Fig. I shows how the activity of glutamine amido transferase varies during the cell cycle in K. fragilis. The general picture is of a continuous increase in activity of the enzyme during the cell cycle with two periods of loss in activity, one of which approximates to the time of cytoplasmic cleavage between mother and daughter cells. This pattern of change was 


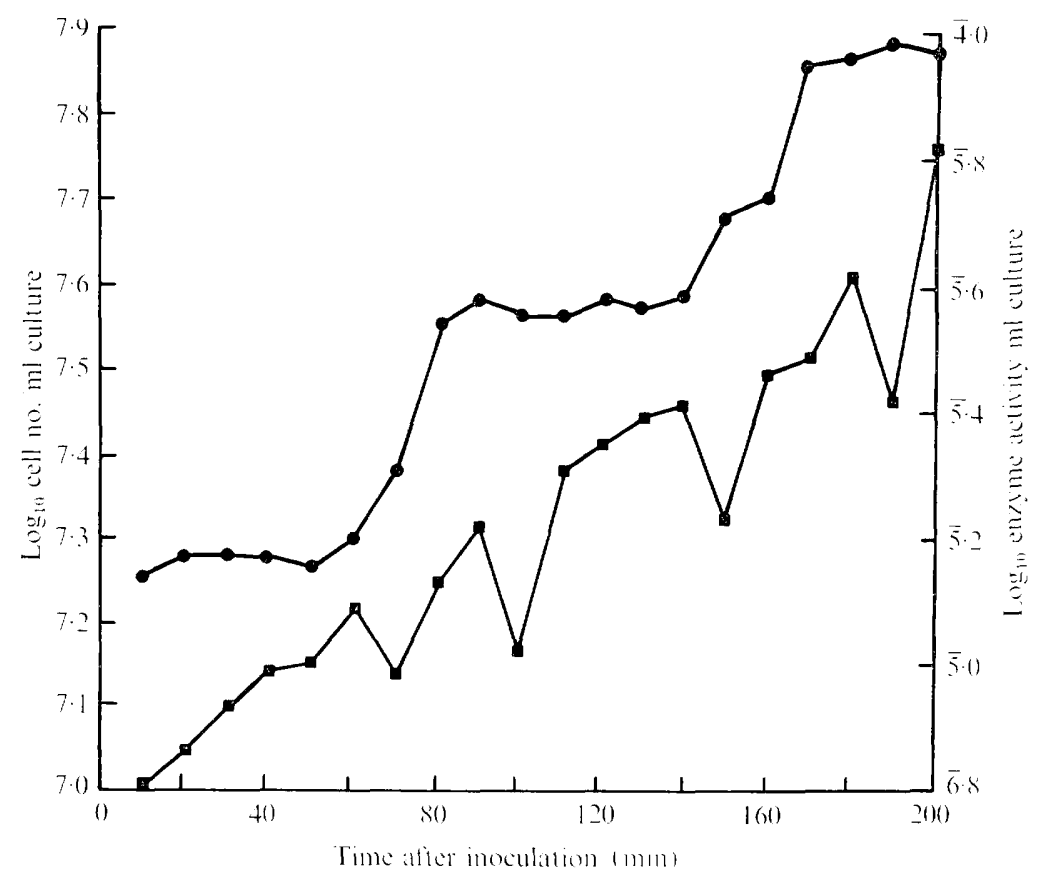

Fig. I. Change in glutamine amido transferase activity in $K$. fragilis in synchronous culture. - $\log _{10}$ cell number/ml culture; $\mathbf{\square}, \log _{10}$ enzyme activity $/ \mathrm{ml}$ culture. Enzyme activity is expressed as change in $E_{540}$ per minute.

demonstrated in four separate experiments and was independent of the length of the cell cycle.

A study of various possible effectors showed that while $\mathrm{Mn}^{2+}$ enhanced enzyme activity markedly (fourfold at a concentration of $7.5 \mathrm{~mm}$ ) $\mathrm{Mg}^{2+}$ had a much smaller activating effect $(25 \%$ at $7.5 \mathrm{~mm}$ ). The effects produced by other compounds depended on the predominant metal ion present. For instance, histidine at a concentration of $8 \mathrm{~mm}$ activated the enzyme by $89 \%$ in the presence of $7.5 \mathrm{~mm}-\mathrm{Mn}^{2}+$ but by only $38 \%$ in the presence of $7.5 \mathrm{mM}-\mathrm{Mg}^{2}$. Tryptophan $(8 \mathrm{~mm})$, on the other hand, had little effect in the presence of $7.5 \mathrm{~mm}-\mathrm{Mn}^{2}-$ but activated by $37 \%$ in the presence of $7.5 \mathrm{~mm}-\mathrm{Mg}^{2+}$, while $8 \mathrm{~mm}$-adenosine $5^{\prime}$-monophosphate inhibited by $34 \%$ in the presence of $7.5 \mathrm{~mm}^{-\mathrm{Mn}^{2+}}$ but had no effect in the presence of $7.5 \mathrm{~mm}^{-\mathrm{Mg}^{2+}}$.

\section{DISCUSSION}

Various patterns of change in enzyme activity have been reported to occur during the cell cycle in yeasts (Duffus, I97I). The results of Folkes, Bishop, Nurse \& Sims (1973) indicate that changes in the activity of glutamine amido transferase, similar to those described above, also occur in Candida utilis, although these authors did not comment on their results. It seems likely that in $K$. fragilis glutamine amido transferase is synthesized throughout the cell cycle and that its activity is lowered rapidly at two specific points. One of these points corresponds to the time at which cytoplasmic division is assumed to have occurred; this is also the time of DNA synthesis (Duffus \& Penman, 1973) and a time at which there is a doubling in the intracellular concentration of $\mathrm{Mg}^{2+}$ (Duffus \& Reid, I973). The other point approximates to the times of doubling of an appreciable fraction $(8.7 \%)$ of the cell protein, 
i.e. the fraction extracting at $\mathrm{pH} 2 \cdot 20$ as described by Duffus \& Penman (1973). Whether these correlations have any significance remains to be seen.

The sudden fall and subsequent rise in glutamine amido transferase at reproducible points in the cell cycle is too rapid to be explained on current ideas of repression of enzyme synthesis. A number of possible explanations suggest themselves. The activity of the enzyme is sensitive to metal ions, amino acids and nucleotides in the assay solutions and, since the yeast extract forms a substantial proportion of the assay solutions, in vivo alterations in the concentrations of in vitro effectors could be responsible for the falls in activity observed. There is also the possibility that the enzyme can exist in active and inactive forms, as with Escherichia coli glutamine synthetase. There is currently no evidence for this mechanism for the $K$. fragilis enzyme (Duffus, unpublished) but the possibility cannot be discounted. Similarly, a change in the solubility of the enzymes might account for the observed results but, though it cannot be ruled out, this seems unlikely since total extractable protein increases throughout the cell cycle without any falls in amount.

The influence of $\mathrm{Mg}^{2+}, \mathrm{Mn}^{2+}$ and adenosine $5^{\prime}$-monophosphate on the enzyme agrees with results obtained with similar enzymes from other sources. However, activation of glutamine amido transferase by amino acids as reported here has not been demonstrated for this enzyme from any other source, though in a few cases activation by amino acids of other enzymes involved in amino acid synthesis has been observed (Kane \& Jensen, 1970; Slaughter, 1970).

Our results indicate that the activity of glutamine amido transferase varies during the cell cycle independently of control of protein synthesis. To understand this better, we must now obtain more information about the nature of the enzyme and its in vitro response to effectors, and establish the fluctuations in vivo in concentrations of metal ions, amino acids and nucleotides during the cell cycle.

This work was supported by SRC grant no. B/RG/06526.

\section{REFERENCES}

Duffus, J. H. (1971). The cell cycle in yeast - a review. Journal of the Institute of Brewing 77, 500-508.

Duffus, J. H. \& Penman, C. S. (1973). Stepwise accumulation of an acid-extractable protein fraction in the budding yeast, Kliyveromyces fragilis, during the cell cycle. Journal of General Microbiology 79, I 89-194.

DufFus, J. H. \& ReID, L. (1973). Changes in cell content of free magnesium and calcium in fission yeast and budding yeast during the cell cycle. Proceedings of the 2nd European Symposium on the Cell Cycle. Veröffentlichungen der Universität Innsbruck $\mathbf{7 7}, 2 \mathrm{I}$.

EATON, N. R. (1962). New press for disruption of micro-organisms. Journal of Bacteriology 83, 1359-1 360 .

Ferguson, A. R. \& Sims, A. P. (1971). Inactivation in vivo of glutamine synthetase and NAD-specific glutamate dehydrogenase: its role in the regulation of glutamine synthesis in yeast. Journal of General Microbiology 69, 423-427.

Ferguson, A. R. \& Sims, A. P. (1974a). The regulation of glutamine metabolism in Candida utilis: the role of glutamine in the control of glutamine synthetase. Journal of General Microbiology 8o, I 59-I 7 I.

Ferguson, A. R. \& Sims, A. P. (1974b). The regulation of glutamine metabolism in Candida utilis: the inactivation of glutamine synthetase. Jownal of General Microbiology 80, I73-I85.

Folkes, B. F., Bishop, R., Nurse, P. M. \& Sims, A. P. (1973). Some aspects of the regulation of amino acid metabolism during the cell cycle of the yeast, Candida utilis. Proceedings of the 2nd European Symposium on the Cell Cycle. Veröffentlichungen der Universität Innsbruck 77, 22-25.

KANE, J. F. \& JeNSEN, R. A. (1970). Metabolic interlock. Influence of histidine on tryptophan biosynthesis in Bacillus subtilis. Jounal of Biological Chemistry 245, 2384-2390.

Mitchison, J. M. \& VinceNT, W. S. (1965). Preparation of synchronous cell cultures by sedimentation. Nature, London 205, 987-989. 
Prusiner, S. \& Stadtman, E. R. (1973). The Enzymes of Glutamine Metabolism. New York and London: Academic Press.

Sims, A. P. \& Ferguson, A. R. (1974). The regulation of glutamine metabolism in Candida utilis: studies with ${ }^{15} \mathrm{NH}_{3}$ to measure in vivo rates of glutamine synthesis. Journal of General Microbiology 80, $\mathrm{I}_{43}-\mathrm{I} 58$.

Shapiro, B. M. \& STADTMan, E. R. (1970). Glutamine synthetase (Escherichia coli). In Methods in Enzymology, vol. 17 A, pp. 910-922. Edited by H. Tabor and C. W. Tabor. New York and London: Academic Press.

Slaughter, J. C. (1970). The activation of 3-phosphoglycerate dehydrogenase by L-methionine. FEBS Letters 7, 245-247.

VAN DER WALT, J. P. (1970). Genus 8. Kluyveromyces van der Walt emend. van der Walt. In The Yeasts a Taxonomic Study, pp. 316-378. Edited by J. Lodder. Amsterdam and London: North Holland Publishing. 